\title{
Mineral Formation under the Influence of Mine Waters (The Kizel Coal Basin, Russia)
}

\author{
Elena Menshikova, Boris Osovetsky, Sergey Blinov and Pavel Belkin * \\ Department of Geology, Perm State University, Bukireva st. 15, Perm 614990, Russia; \\ menshikova_e@list.ru (E.M.); opal@psu.ru (B.O.); blinov_s@mail.ru (S.B.) \\ * Correspondence: pashabelkin@mail.ru
}

Received: 21 February 2020; Accepted: 15 April 2020; Published: 17 April 2020

\begin{abstract}
The development of coal deposits is accompanied by negative environmental changes. In the territory of the Kizel coal basin (Perm Region, Russia), the problem of contamination of water sources by acid mine waters and runoff from rock dumps is particularly acute. Mine waters are acidic ( $\mathrm{pH} 2-3$ ), with high mineralization (up to $25 \mathrm{~g} / \mathrm{L}$ ) and significant content of sulfate ions, iron, aluminum, manganese, toxic trace elements ( $\mathrm{As}, \mathrm{Co}, \mathrm{Ni}, \mathrm{Pb}$ and $\mathrm{Zn}$ ). They are formed as a result of the interaction of underground waters from flooded mines of the Kizel basin with coal and rocks of dumps with high sulfur content (15\%). Uncontrolled inflow of mine water into rivers (about 22 million $\mathrm{m}^{3}$ annually) leads to significant amounts of iron and aluminum hydroxide precipitation. These precipitations are in active interaction with river water, polluting the rivers tens of kilometers downstream and are entering the Kama reservoir. Studies of alluvial precipitation can be considered as a method of control and predictors of technogenic water pollution. The mineral composition of river sediments was studied with the application of different methods, including studies of sand-gravel and silty-clayey sediments. The sandy-gravel grains in the bottom load are mainly composed by natural minerals and are represented by a significant number of particles of coal dumps, slags and magnetic spherules. The silty-clayey material, mixed with natural minerals, contains a significant number of amorphous phases with a predominance of iron-rich substances, which may actively concentrate toxic elements. The presence of jarosite, goethite, basaluminite, lepidorocite and copiapite in silty-clayey sediments are indicators of the influence of mine waters.
\end{abstract}

Keywords: AMD-precipitates; AMD-minerals; mine water; waste rock dumps; river systems; sedimentation; migration; Kizel coal basin; the Western Urals

\section{Introduction}

Modern alluvial sediments as one of the components within the upper part of the lithosphere are a traditional object of study of geological sciences, and an important element of the environment. Alluvial sediments integrate geochemical and mineral features of catchment rocks, and rivers are a link between areas of sediment mobilization in catchments and large sediment accumulation basins [1]. The alluvium composition makes it possible to identify the migration flows of matter, the zone of anthropogenic influence, and thus is used as an indicator of anthropogenic impact on water bodies. The authors have conducted studies of the impact of coal mining on the current state of the river ecosystems in Kizel coal basin (Perm Region). In this work the mineralogy of the river deposits in a polluted region is considered.

Coal mining, which has been carried out in the Kizel basin for over 200 years, has now been stopped. The cessation of mining activities and the inundation of mines did not lead to the solution of environmental problems. The main factors of the territory contamination are the self-diffusion of acidic mine waters and the runoff of rock dumps and industrial sites [2-4]. Mine waters flow into 19 rivers of 
the territory. In modern conditions, some rivers are polluted even more intensely and over a longer period of time than during the operation of coal mines. The scale of this process is demonstrated by the analysis of multiyear series of space images of this territory [5]. The entry of spontaneous mine water into rivers resulted in formation of considerable volumes of technogenic sediments.

The study area is located within the Western Urals folding zone adjacent to the Pre-Urals foredeep, and is composed of Paleozoic rocks (from the Middle Devonian to Lower Perm inclusive) and covering them with Quaternary deposits. The carbonaceous sequence (the Visean stage of Lower Carboniferous) is represented by sandstones, siltstones, argillites and clay shales with limestone interlayers. The rocks of the carbonaceous sequence include finely dispersed pyrite and organic sulfur. The content of sulfide and organic sulfur reaches $12 \%-15 \%$. Sulfur is one of the main active elements of the coal-bearing rocks, determining acid-alkaline and redox conditions of sediment accumulation, concentration of elements in the reducing geochemical environment (with the presence of $\mathrm{H}_{2} \mathrm{~S}$ ), their leaching in the oxidation zone with the formation of products affecting the ecological condition of the territory.

The purpose of the present research is an estimation of the migration and sedimentary processes of formation of modern alluvial deposits in the territory of the Kizel coal basin with consideration of applied ecological aspects. The study of the mineral occurrence forms of the substances in river sediments for areas affected by mine water discharge is of great importance, as supergenic formation of secondary minerals is the most important natural process for removing a number of elements from such solutions. These minerals represent a dynamic system in which mineralogical and chemical transformations can be caused by sudden changes in chemical and physical conditions [6-8]. Evolution of acidic sulphate waters results in a number of rather insoluble hydroxysulfate and oxyhydroxide $\mathrm{Fe}$ and Al minerals, which are precipitated during oxidation, hydrolysis and neutralization. These minerals, as a rule, have low crystallinity, coexist with intermediate and high crystalline phases, and are difficult to describe $[9,10]$. Secondary natural iron minerals have a higher retention capacity than their synthetic counterparts [11].

Although the study of secondary minerals in mine water is the subject of several studies, the role of these precipitates, their properties and associations remain a relevant topic of research, namely for the still unknown effects they may have on the ecosystems. Therefore, the present work contributes with novel results about the processes of natural and anthropogenic mineral formation in an abandoned coal basin. This research shows the specificity of mineral associations in bottom sediments and reflects the scales of display of processes of transformation in modern alluvium.

\section{Methods}

The study areas are located at the Vilva, Usva (the Chusovaya River basin), Kizel, Vilva (the Yaiva River basin), and Kosva Rivers and their tributaries, into which the mine water is discharged or has ever been discharged. The sampling scheme takes into account background areas that were not affected by anthropogenic factors. Suspended load material (aleurite clayey sediments) and bottom load material (sandy and sandy-gravel) were sampled. A total of 72 samples were taken at 36 sites. The locations of some sampling point are shown in the scheme (Figure 1).

The mineral composition of sandy and sandy-gravel sediments was characterized on the basis of optical analysis of 1000 grains in $0.25-0.1 \mathrm{~mm}$ fraction (Nikon SMZ 745, Nikon, Tokyo, Japan) as the most representative in terms of mineral diversity, and the composition of silty-clay sediments was analyzed by X-ray diffraction analysis (D2 Phaser, Bruker, Billerica, MA, USA).

The movable forms of pollutants have been estimated on the basis of general chemical analysis of water extraction from alluvial deposits (ratio of $100 \mathrm{~g}$ of ground per $500 \mathrm{~mL}$ of water, method of analysis-titrometry). The sum of water-soluble salts is the sum of all ions found by chemical analysis in the bottom sediments (in $\mathrm{mg} / \mathrm{kg}$ of ground). 


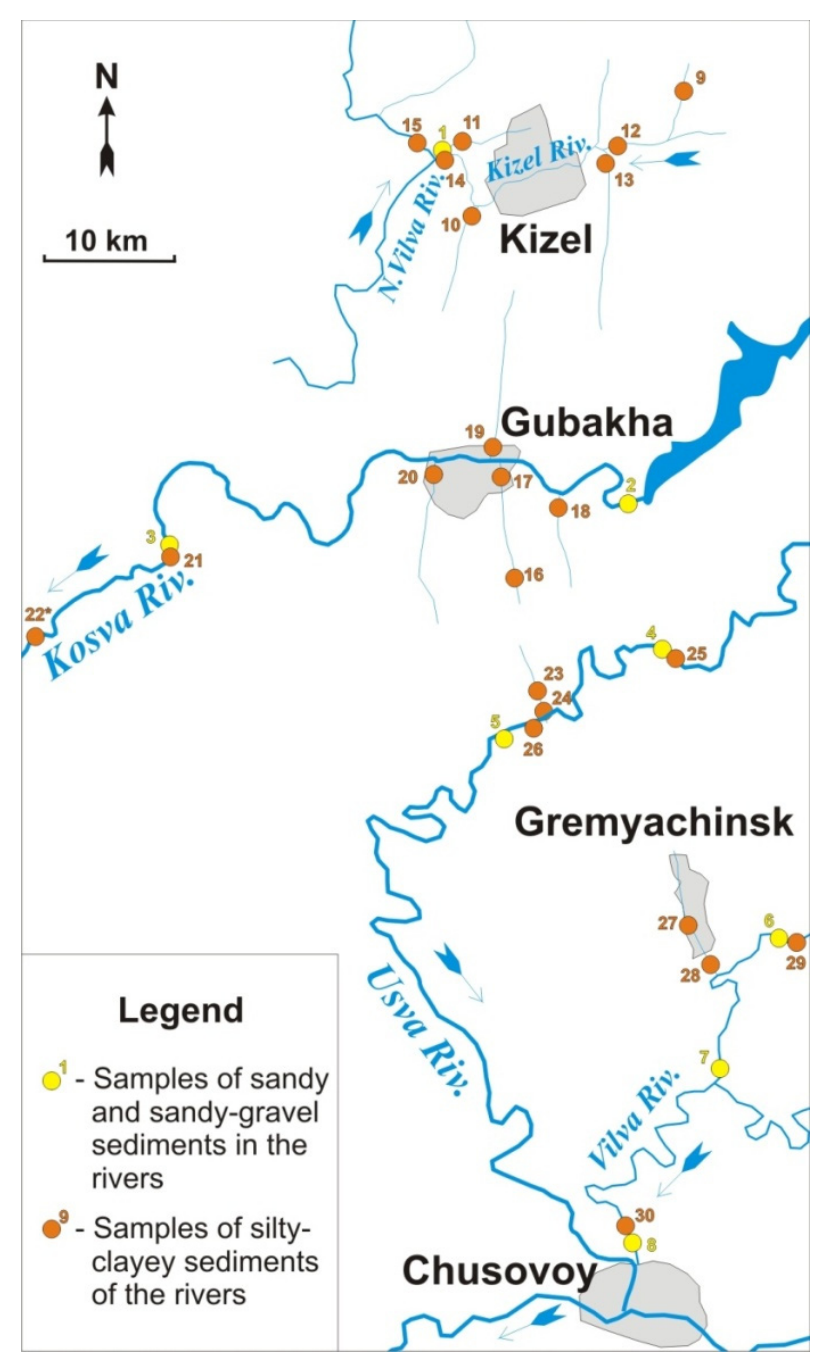

Figure 1. Scheme of sampling places.

X-ray fluorescent (S8 Tiger, Bruker) and inductively coupled plasma mass spectrometry (ICP-MS) (Aurora M90, Bruker) analyses were used to determine the chemical composition of individual alluvial sediments. The particle size distribution of sediments was determined by the sieve method and by using a particle size analyzer (Analysette 22 Micro Tec plus, Fritsch). A scanning electron microscope (JSM 6390 LV, Jeol, Tokyo, Japan) with microprobe analysis (EDS INCA 350 Energy, Oxford Instruments, Abingdon, UK) was used for study of certain types of technogenic products in the bottom sediments.

\section{Results and Discussion}

According to the conducted researches the mineral composition of sand alluvial deposits of the investigated rivers is rather diverse. In uncontaminated sediments on a background of dominant quartz there are feldspars, talc, carbonates (the content is $3 \%-11 \%$ ), chlorite, amphibole, epidote, pyroxenes, chromite, magnetite, hematite, leucoxene, hydrogoethite, ilmenite (as a rule, in the quantity of $0.1 \%-2 \%$ ) (Table 1 ). In quantities less than $0.1 \%$ there are garnets, actinolite, rutile. The mineral composition of silty-clayey sediments is presented by quartz, plagioclases and clay minerals (kaolinite, illite, hydromica, smectite and chlorite) (Table 2). 
Table 1. Mineral composition of sandy and sandy-gravel sediments in the rivers.

\begin{tabular}{|c|c|c|c|c|}
\hline $\begin{array}{l}\text { Place of Sampling } \\
\text { (Number in } \\
\text { Figure 1) }\end{array}$ & Character of Influence & $\begin{array}{l}\text { Natural Mineral } \\
\text { Association *, \% }\end{array}$ & Other Natural Minerals **, \% & Technogenic Particles, $\%$ \\
\hline \multicolumn{5}{|c|}{ Basin of the Yaiva River } \\
\hline $\begin{array}{l}\text { The Kizel River, } \\
\text { mouth (1) }\end{array}$ & $\begin{array}{l}\text { Rock dumps on the } \\
\text { catchment area and } \\
\text { coastal zone, } \\
\text { mine drainage }\end{array}$ & $\begin{array}{c}\text { quartz (56), } \\
\text { feldspars (13) }\end{array}$ & $\begin{array}{c}\text { iron hydroxides } * * *(3.5), \text { pyroxenes }(1.3) \\
\text { magnetite }(1.1), \text { epidote }(0.3)\end{array}$ & $\begin{array}{l}\text { coal-rock particles }(22) \\
\text { slag }(2.7), \text { magnetic } \\
\text { spherules }(0.3)\end{array}$ \\
\hline \multicolumn{5}{|c|}{ Basin of the Kosva River } \\
\hline $\begin{array}{c}\text { The Kosva River, } \\
\text { upstream (2) }\end{array}$ & Background area & $\begin{array}{l}\text { quartz (69), } \\
\text { carbonates (11) }\end{array}$ & $\begin{array}{c}\text { chlorite }(2), \text { amphibole }(1.8), \text { epidote }(1.4), \\
\text { pyroxenes }(0.9) \text {, chromite }(0.9) \text {, magnetite } \\
(0.5), \text { hematite }(0.5) \text {, iron hydroxides }(0.2) \\
\text { and others }\end{array}$ & coal-rock particles (2) \\
\hline $\begin{array}{l}\text { The Kosva River, } 40 \\
\text { km downstream (3) }\end{array}$ & $\begin{array}{l}\text { Rock dumps on the } \\
\text { catchment area and } \\
\text { coastal zone, } \\
\text { mine drainage }\end{array}$ & quartz (58) & $\begin{array}{c}\text { carbonates }(2.6) \text {, talc }(2.1), \text { feldspar }(1.9), \\
\text { chlorite }(1.9) ; \text { amphibole }(1.5) \text {, epidote }(1.2), \\
\text { pyroxenes }(0.6), \text { iron hydroxides }(0.4), \\
\text { magnetite }(0.4), \text { garnets }(0.3) \text {, chromite }(0.3) \\
\text { and others }\end{array}$ & $\begin{array}{l}\text { coal-rock particles (19.8), } \\
\text { slag (6.5), } \\
\text { magnetic spherules (1.1) }\end{array}$ \\
\hline \multicolumn{5}{|c|}{ Basin of the Chusovaya River } \\
\hline The Usva River (4) & Background area & $\begin{array}{l}\text { quartz (85) } \\
\text { talc (4) }\end{array}$ & $\begin{array}{c}\text { feldspars (1.9), chlorite (1.9), amphibole } \\
\text { (0.8), epidote(0.6), pyroxenes (0.3), } \\
\text { iron hydroxides (0.1), magnetite (0.1), } \\
\text { hematite(0.1) and others }\end{array}$ & $-* * * *$ \\
\hline $\begin{array}{l}\text { The Usva River, } \\
\text { below the mouth } \\
\text { Rudyanka River (5) }\end{array}$ & $\begin{array}{l}\text { Supply of contaminated } \\
\text { river water }\end{array}$ & $\begin{array}{l}\text { quartz }(68) \\
\text { feldspars }(4) \\
\text { talc }(4)\end{array}$ & $\begin{array}{c}\text { chlorite (2.8), epidote }(1.3) \text {, amphibole }(1.0), \\
\text { magnetite }(1.0), \text { iron hydroxides }(0.7), \\
\text { pyroxenes }(0.5), \text { actinolite }(0.3) \text {, hematite } \\
(0.2), \text { ilmenite }(0.2) \text {, garnets }(0.1) \\
\text { rutile }(0.1) \text { and others }\end{array}$ & $\begin{array}{l}\text { coal-rock particles }(0.5) \\
\text { slag }(0.2), \text { magnetic } \\
\text { spherules }(0.2)\end{array}$ \\
\hline The Vilva River (6) & Background area & $\begin{array}{l}\text { quartz }(68) \\
\quad \text { talc }(9)\end{array}$ & $\begin{array}{c}\text { feldspars (2.9), pyroxenes (1.2), epidote } \\
(1.0), \text { magnetite }(0.7) \text {, amphibole }(0.6), \\
\text { hematite (0.5), iron hydroxides }(0.2) \\
\text { ilmenite }(0.2), \text { chromite }(0.1)\end{array}$ & $-^{* * * *}$ \\
\hline $\begin{array}{l}\text { The Vilva River, } \\
\text { downstream (7) }\end{array}$ & $\begin{array}{l}\text { Supply of contaminated } \\
\text { river water }\end{array}$ & $\begin{array}{l}\text { quartz (82), } \\
\text { talc (4) }\end{array}$ & $\begin{array}{c}\text { feldspars }(2.0) \text {, chlorite }(2.0) \text {, epidote }(0.5), \\
\text { amphiboles }(0.5), \text { pyroxenes }(0.2), \\
\text { iron hydroxides }(0.2), \text { actinolite }(0.1) \\
\text { magnetite }(0.1) \text { and others }\end{array}$ & coal-rock particles $(0.1)$ \\
\hline $\begin{array}{l}\text { The Vilva River, } \\
\text { mouth (8) }\end{array}$ & & $\begin{array}{l}\text { quartz (75), } \\
\text { epidote (4) }\end{array}$ & $\begin{array}{c}\text { talc (3.5), chlorite (1.8), amphibole (1.4), } \\
\text { pyroxenes }(0.5) \text {, iron hydroxides }(0.5), \\
\text { actinolite }(0.4), \text { magnetite }(0.4), \text { ilmenite } \\
(0.3) \text {, haematite }(0.1), \\
\text { chromite }(0.1) \text { and others }\end{array}$ & magnetic spherules $(0.3)$ \\
\hline
\end{tabular}

In the river sections located in the zone of influence of the coal deposit development and downstream, there is a change in the mineral composition of bottom sediments, which is clearly recorded not only by the results of laboratory mineralogical studies, but also directly in the field conditions. In particular, detritus material in river sediments, which are currently receptors of mine spills, is covered with a red layer of iron hydroxides. Iron hydroxides are also present in the form of individual particles, among which lamellar individuals predominate. They are often formed by replacing plant residues and often preserve the fibrous or layered structure of plants. In addition, crusts, deposits and aggregates are also present. They come in various sizes, including finely dispersed aggregates. Most noticeable is their presence in the class of 1-0.5 mm particles. Lemon-yellow differences prevail in color, but bright red particles are also observed in some places. Under the electron microscope, the inhomogeneity of the internal structure of these glandular products is detected, which is manifested by the presence of a highly porous structure and a cellular surface of the particles. Among them there are sometimes fragments with sharp edges, which testify to their extreme fragility. Probably when transported in a water stream, such particles are easily crushed, frayed and partially suspended.

In the silty-clayey sediments composition, along with natural mineral grains, in significant quantities there are components due to the specifics of man-made impact-coal-bearing particles (up to $22 \%$ ), slags (up to $6.5 \%$ ) and magnetic spherules (up to $1.1 \%$ ) [12]. The main source of such technogenic products is coal mine dumps. 
Table 2. Mineral composition of silty-clayey sediments of the rivers.

\begin{tabular}{|c|c|c|c|}
\hline $\begin{array}{l}\text { Place of Sampling } \\
\text { (Number in Figure 1) }\end{array}$ & Character of Influence & Natural Mineral Association * \% & Secondary Minerals, $\%$ \\
\hline \multicolumn{4}{|c|}{ Basin of the Yaiva River } \\
\hline The North Kizel River (9) & Background area & quartz (52), plagioclases (23), clay minerals (9) ** & $-* * *$ \\
\hline The Sukhoi Kizel River, mouth (10) & Mine drainage in the past and & $\begin{array}{l}\text { quartz (36), plagioclases (10), potassium } \\
\text { feldspars (4) }\end{array}$ & goethite (7) \\
\hline The Viejasher River, mouth (11) & & quartz (25), clay minerals (12), plagioclases (7) & jarosite (3), goethite (2) \\
\hline The East Kizel River, mouth (12) & & quartz (13), clay minerals (4) & goethite (15) \\
\hline $\begin{array}{l}\text { The Poludenyi Kizel River, mouth (13) } \\
\text { The Kizel River, mouth (14) }\end{array}$ & Mine drainage & $\begin{array}{c}\text { quartz (15), clay minerals (3) } \\
\text { quartz (5) }\end{array}$ & $\begin{array}{l}\text { lepidocrocite (3), goethite (2) } \\
\text { jarosite (4) }\end{array}$ \\
\hline $\begin{array}{l}\text { The North Vilva River, } 500 \mathrm{~m} \text { below } \\
\text { the mouth of the Kizel River (15) }\end{array}$ & Contaminated river water runoff & quartz (15), clay minerals (4) & $\begin{array}{l}\text { jarosite (11), goethite (9), } \\
\text { lepidocrocite (4), diaspore (2) }\end{array}$ \\
\hline \multicolumn{4}{|c|}{ Basin of the Kosva River } \\
\hline The Ladeynaya Log River (16) & Background area & quartz (68), plagioclases (17), clay minerals (7) & goethite (3) \\
\hline The Ladeynaya Log River, mouth (17) & Mine drainage & quartz (30), plagioclases (12), clay minerals (7) & goethite (3) \\
\hline The Shumikha River, mouth (18) & $\begin{array}{l}\text { Runoff from waste dumps, impact of } \\
\text { sludge collector }\end{array}$ & quartz (27), clay minerals (21) & $\begin{array}{c}\text { basaluminite (8), jarosite (1), } \\
\text { goethite (1) }\end{array}$ \\
\hline $\begin{array}{l}\text { The Gubashka River, mouth (19) } \\
\text { The Kamenka River, mouth (20) }\end{array}$ & $\begin{array}{l}\text { Mine drainage in the past and } \\
\text { wastewaters from rock dumps }\end{array}$ & $\begin{array}{l}\text { quartz (36), clay minerals (9), plagioclases (9) } \\
\text { quartz (40), clay minerals (13) }\end{array}$ & $\begin{array}{l}\text { goethite (2) } \\
\text { goethite (1) }\end{array}$ \\
\hline $\begin{array}{l}\text { The Kosva River, } 40 \mathrm{~km} \text { downstream } \\
\text { of the mine site (21) }\end{array}$ & $\begin{array}{l}\text { Mine drainage and wastewaters from } \\
\text { rock dumps }\end{array}$ & quartz (20), clay minerals (8), plagioclases (4) & goethite $(<1)$ \\
\hline $\begin{array}{l}\text { The Kosva River, } 70 \mathrm{~km} \text { downstream } \\
\text { of the mine site (22) }\end{array}$ & & quartz (10) & $-* * *$ \\
\hline \multicolumn{4}{|c|}{ Basin of the Chusovaya River } \\
\hline The Rudyanka River (23) & Background area & quartz (77), clay minerals (9), plagioclases (4) & goethite (1) \\
\hline The Rudyanka River, mouth (24) & Mine drainage & quartz (27), clay minerals (11) & goethite (1) \\
\hline The Usva River (25) & Background area & quartz (66), clay minerals (7), plagioclases (5) & goethite (1) \\
\hline $\begin{array}{l}\text { The Usva River, below the mouth of } \\
\text { the River Rudyanka (26) }\end{array}$ & $\begin{array}{l}\text { Mine drainage, runoffs from rock } \\
\text { dumps, contaminated river water } \\
\text { runoff }\end{array}$ & quartz (15), clay minerals (12) & goethite (1.5), jarosite (1) \\
\hline The Bolshaya Gremyachaya River (27) & \multirow{2}{*}{$\begin{array}{c}\text { runoft } \\
\text { Mine drainage }\end{array}$} & quartz (34) & jarosite (45) \\
\hline $\begin{array}{l}\text { The Bolshaya Gremyachaya River, } 5 \\
\mathrm{~km} \text { below discharge mine water }(28)\end{array}$ & & quartz (15), clay minerals (6) & copiapite (2) \\
\hline The Vilva River (29) & Background area & quartz (70), plagioclases (18), clay minerals (10) & goethite $(<1)$ \\
\hline The Vilva River, mouth (30) & Supply of contaminated river water & quartz (4) & lepidocrocite (2) \\
\hline
\end{tabular}

Among the objects studied the highest content of technogenic material is found in alluvial deposits of the Kosva River, the whole right bank of which on territory of the town of Gubakha is covered with rocks of mine dumps. Downstream of the river silty-clayey sediments are painted black due to the high content of coal-bearing and slag particles. There are nearshore shoals, more than $90 \%$ of which are formed by anthropogenic material of sandy size.

Carbonaceous particles have a high migration capacity. They migrate as a part of the bottom, and particularly as suspended load, as well as by air at considerable distances. The territory of the Kizel basin is characterized by pyrite-containing carbonaceous particles. Although the latter are noticeably inferior to pure coal in terms of migration capacity, they are also actively transported by the Kosva River system. Calculations have shown that their migration capacity approximately corresponds to that of quartz particles [13]. Morphologically carbonaceous particles with pyrite are noticeably different from pure coal. They are characterized by a variety of forms (flattened, angular, elongated, etc.), relatively weak roundness, uneven surface, on which numerous pyrite inclusions can be seen (Figure 2). Particles of pyrite in coal are very diverse. Among them there are crystals up to $0.2 \mathrm{~mm}$ in size in the form of octahedron and cube, which often form tightly fused aggregates. According to microprobe analysis pyrite from coal particles contains a variable complex of toxic elements (As, $\mathrm{Co}, \mathrm{Ni}, \mathrm{Cu}, \mathrm{Zn}, \mathrm{Sb}$, and Se). Arsenic, the content of which is determined with the greatest accuracy using a wave spectrometer, is noted in each pyrite-containing sample. Its content varies from $0.045 \%$ to $0.51 \%$, but values from $0.15 \%$ to $0.25 \%$ prevail. There is no doubt that a considerable portion of toxic elements in the process of pyrite decomposition passes into the water medium [14]. At the same time, the forms of their occurrence can be different: colloidal formations (micelles), suspended iron hydroxide, arsenic acid, etc. 

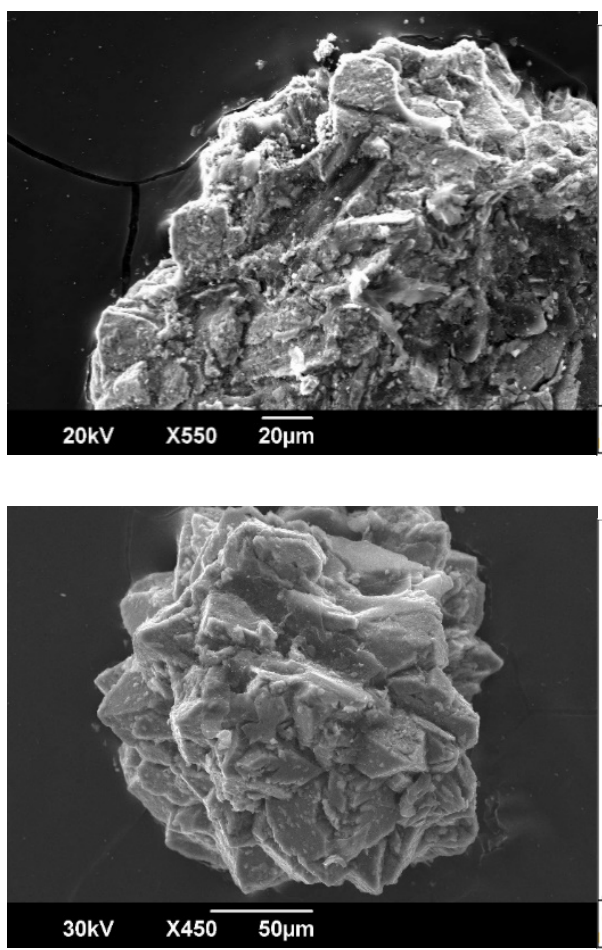

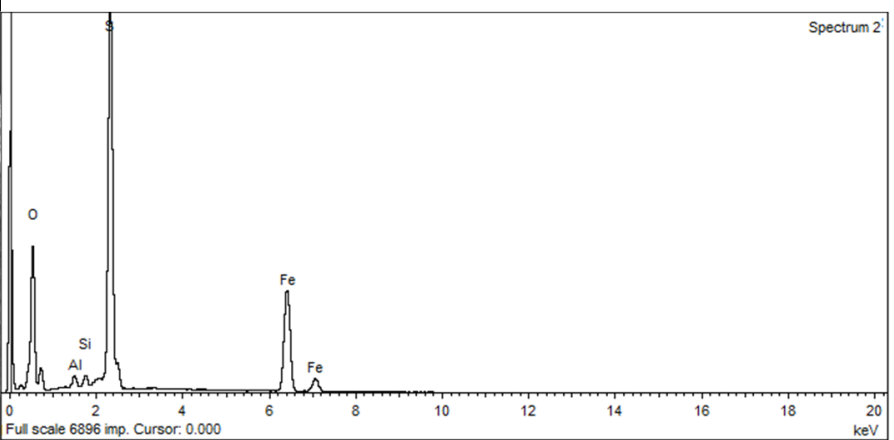

(a)

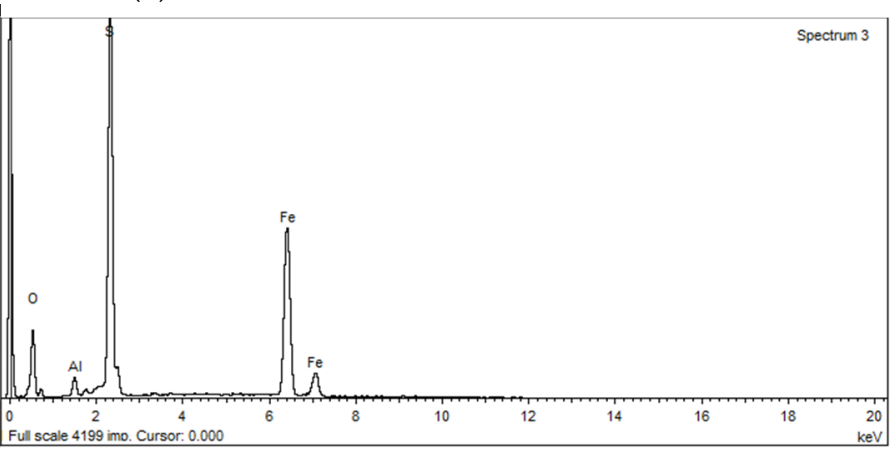

(b)

Figure 2. Clayey particles with pyrite from the Kosva River alluvium: (a) a fragment of a coal particle with pyrite crystals on the surface, (b) an aggregate of cubic and octahedral pyrite crystals isolated from the coal particles.

Magnetic spherules in alluvial sediments of the Kizel coal basin (Figure 3), according to the microprobe analysis, belong to iron (magnetite) and silicate-iron (modified magnetite aggregates) groups [15]. Iron spherules are characterized by correct spherical shape, strong semi-metallic luster, black color, smooth surface and small size (usually less than $100 \mu \mathrm{m}$ ). They have the highest magnetic susceptibility values. The share of iron oxides in their chemical composition exceeds $80 \%$. Characteristic components reflecting the degree of change in the chemical composition of spherules are $\mathrm{SiO}_{2}, \mathrm{Al}_{2} \mathrm{O}_{3}$, $\mathrm{CaO}$ and $\mathrm{K}_{2} \mathrm{O}$. The spherules, which are more affected by the changes (presence of caverns, cavities and cracks filled with secondary substances), are characterized by lower iron oxide content and higher silica and alumina content.

Silicate-iron spherules are grey or brownish in color, have a matte luster, rough surface and larger sizes. They have a lower magnetic susceptibility compared to the previous group. In their chemical composition the content of iron oxides decreases to $78 \%-55 \%$, respectively of the content of $\mathrm{Si}, \mathrm{Al}, \mathrm{Ti}, \mathrm{Ca}$ and $\mathrm{Mg}$; while sometimes $\mathrm{Na}, \mathrm{K}$ and $\mathrm{Mn}$ increases. Typical indicators of the impact of environmental chemical agents on spherules are increased contents of phosphorus and sulfur compounds in their composition. The maximum concentration of spherules is found in sediments of the Kosva River at a distance of $22 \mathrm{~km}$ below of the town of Gubakha, where the coke production is located, which is considered as the main source of their supply.

In the overwhelming majority of silty-clayey material of the investigated rivers, the zones of anthropogenic influence have a bright orange and rusty color. It is deposited on shallows, and covers coarse-grained deposits. X-ray amorphous iron phases may account for a significant proportion of its composition, which demonstrates a high percentage of the revealed crystalline phases for the background areas (assuming a total of $80 \%-90 \%$ ) and their significantly lower content for river areas in the zone of influence of mine water and waste water from rock dumps. It is this finely dispersed phase of sediment-sorbing the toxic elements $\mathrm{As}, \mathrm{Co}, \mathrm{Ni}, \mathrm{Pb}$ and $\mathrm{Zn}$, on the one hand-that provides the processes of self-purification of water, on the other hand, and is a source of secondary pollution of water 
at the sites of active accumulation, which is confirmed for a number of other mining areas $[8,16,17]$. The study of the granulometry of such sediments showed a one-modal distribution of these particles by size with a distinct mode, usually in a narrow class of $16-8 \mu \mathrm{m}$.
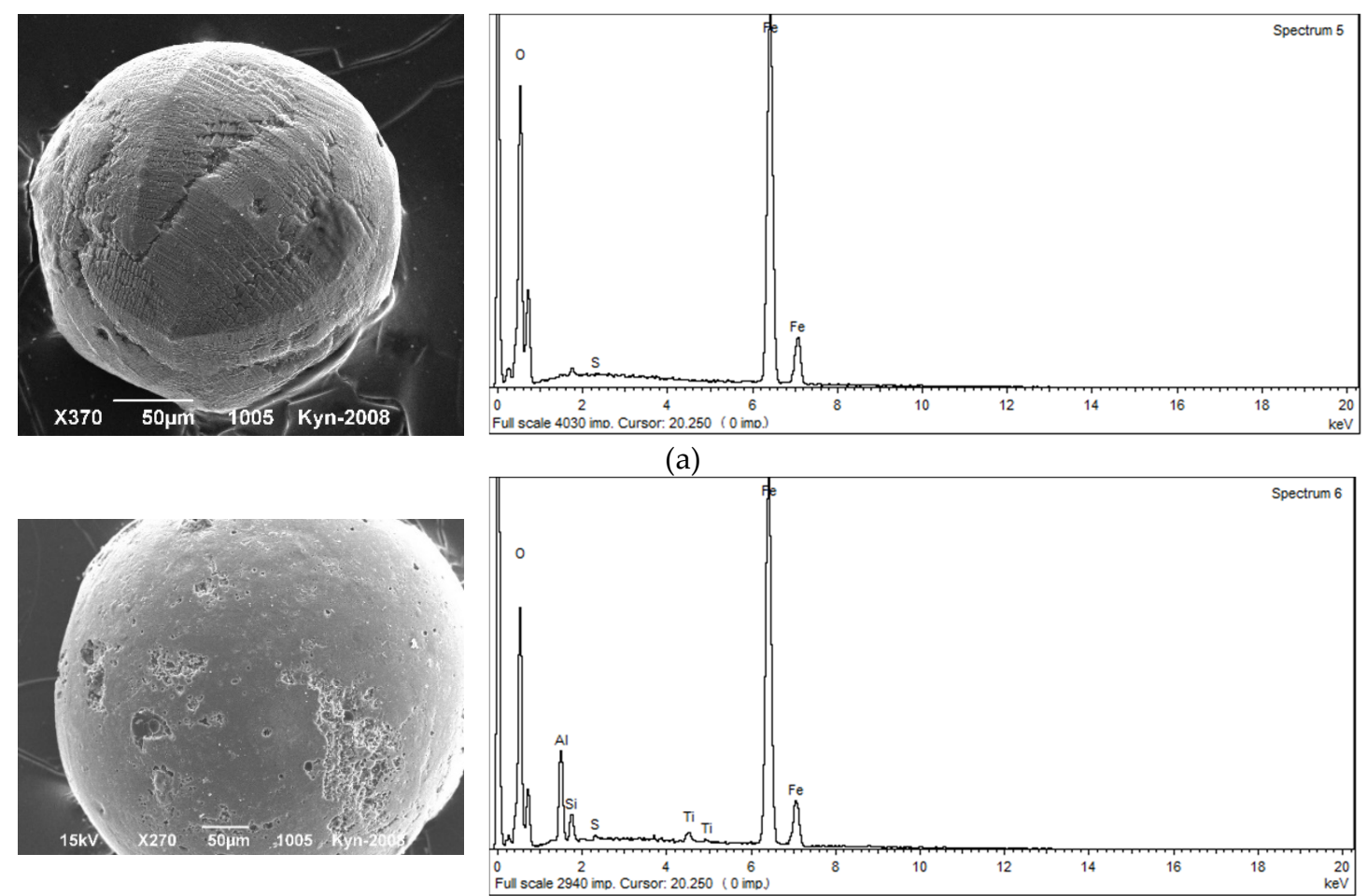

(b)
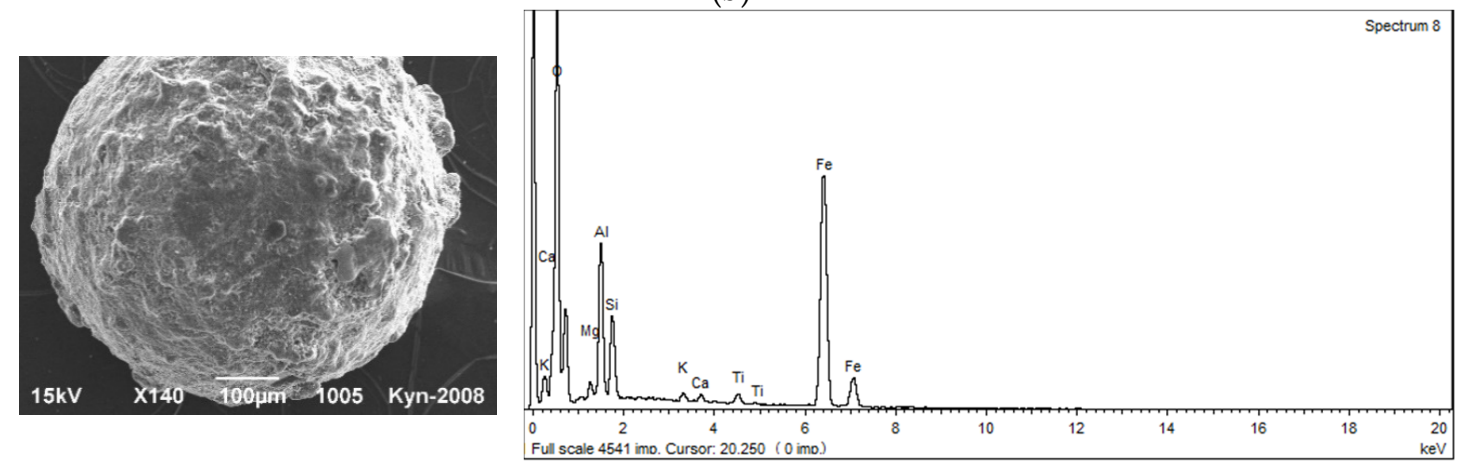

(c)

Figure 3. Morphology of typical magnetic spherules: (a) tiled microsculpture of the surface with a distinct separation of octants (the Kosva River), (b) initial stage of spherula change with separate corroded areas of the surface (the Kizel River), (c) stage of a strong spherula change (the Kizel River).

Secondary minerals (\%) are present in the crystallized part of silty-clayey sediments: goethite-up to $15 \%$, jarosite - up to $45 \%$, basaluminite - up to $8 \%$, lepidocrocite - up to $4 \%$, diaspore and copiapite-up to $2 \%$.

An example of the maximum manifestation of secondary mineral formation processes is the area of mixing neutral waters of the Vilva River with waters of the Kizel River saturated with suspended, colloidal and dissolved substances. Here in silty-clayey sediments are found (\%): jarosite (up to $11 \%$ ), goethite (up to $9 \%$ ), lepidocrocite (up to $4 \%$ ), diaspore (up to $2 \%$ ), which are absent in the upstream of the Vilva River. These mineral phases, formed by sulfide oxidation processes, are among the most common in other mining areas as well [6,18-21]. Goethite is the most stable in hypergenic conditions in this group ( $\mathrm{pH}$ range 2.5-7) [22], and therefore it is widely distributed in the group of secondary river sediment minerals for this area. 
According to the analysis of water extraction silty-clayey sediments in natural conditions have close to neutral reaction of medium $(\mathrm{pH}=6.3-7.6)$ and low content of water-soluble substances-200-600 mg/kg (Table 3). The extractor hood has a hydrogen carbonate-calcium composition and low concentrations of pollutants, which are typical for mine waters.

Table 3. Chemical composition of water extraction from bottom sediments in the Kizel coal basin rivers, $\mathrm{mg} / \mathrm{kg}$ ground.

\begin{tabular}{|c|c|c|c|c|c|}
\hline \multirow[b]{2}{*}{ Components } & \multirow[b]{2}{*}{$\begin{array}{l}\text { Background } \\
\text { Areas }(\mathrm{n}=9)\end{array}$} & \multicolumn{3}{|c|}{$\begin{array}{l}\text { Plots of Modern Supply of Mine Water, } \\
\text { Distances from the Spillage }\end{array}$} & \multirow[b]{2}{*}{$\begin{array}{c}\text { Rivers That Were } \\
\text { Previously } \\
\text { Discharged by } \\
\text { Mine Water }(n=8)\end{array}$} \\
\hline & & $\begin{array}{l}\text { Up to } 1 \mathrm{~km} \\
\quad(\mathrm{n}=7)\end{array}$ & $\begin{array}{l}1 \text { to } 10 \mathrm{~km} \\
(\mathrm{n}=6)\end{array}$ & $\begin{array}{l}\text { Several Tens } \\
\text { of Kilometers } \\
\text { (Downstream } \\
\text { Areas) }(n=6)\end{array}$ & \\
\hline $\mathrm{pH}$ & $6.3-7.6$ & $3.0-3.6$ & $5.4-6.7$ & $6.1-7.3$ & $6.0-7.3$ \\
\hline $\mathrm{HCO}_{3}{ }^{-}$ & $76.3-369.2$ & n.a. & $125.1-750.5$ & $756.6-1882.4$ & $88.5-286.8$ \\
\hline $\mathrm{SO}_{4}^{2-}$ & $57.7-257.0$ & 2367.9-16702.7 & $790.1-4135.5$ & $963.0-4404.4$ & 64.9-1491.4 \\
\hline $\mathrm{Cl}^{-}$ & $8.9-31.9$ & $143.6-443.1$ & $93.9-544.2$ & $83.3-533.6$ & $10.7-58.5$ \\
\hline $\mathrm{Ca}^{2+}$ & $13.0-133.3$ & $164.4-796.6$ & $82.2-1109.2$ & $654.3-1762.5$ & $88.2-503.0$ \\
\hline $\mathrm{Mg}^{2+}$ & $4.3-27.4$ & $60.2-724.3$ & $12.8-148.3$ & 75.4-198.1 & $16.4-132.5$ \\
\hline $\mathrm{Na}^{+}+\mathrm{K}^{+}$ & $12.7-62.1$ & $26.5-790.9$ & $20.7-152.9$ & $85.1-403.5$ & $6.9-150.6$ \\
\hline $\mathrm{Fe}$ & n.a. -6.6 & $688.3-5272.1$ & $93.8-810.2$ & $5.7-74.1$ & n.a.-15.0 \\
\hline $\mathrm{Al}^{3+}$ & n.a. -0.6 & $29.4-152.7$ & $0.6-8.5$ & n.a. -0.6 & n.a. -0.8 \\
\hline $\begin{array}{c}\text { Sum of } \\
\text { water-soluble salts }\end{array}$ & $198.5-606.1$ & $3711.8-24768.2$ & $2048.9-7407.8$ & 3958.3-9333.4 & $493.6-2528.8$ \\
\hline
\end{tabular}

$\mathrm{n}$-number of samples, n.a.-component was not detected by the analysis, $\mathrm{CO}_{3}{ }^{2-}-$ component was not detected by the analysis.

Rivers below the inflow of mine spills can be divided into three zones by the intensity of change in the chemical composition of alluvial deposits (Figure 4). The largest change is observed in the areas up to $1 \mathrm{~km}$ below the inflow of mine waters. The content of water-soluble substances here increases by 20-40 times in comparison with the initial one. The extractor hood has an acidic reaction of medium $(\mathrm{pH}=3-3.6)$ and sulfate-iron composition. For some rivers the concentration of mobile forms of iron is 800 , aluminum 25, sulfates 65 times higher than the background values. Absence of hydrogen carbonate ion in the water extraction of bottom sediments at river sections adjacent to mine spills is explained by low $\mathrm{pH}$ values. From amorphous iron hydroxides in river sediments here occurs the formation of goethite and jarosite (in favorable conditions for crystallization the content of jarosite may be $45 \%$ ).

Downstream, at a distance of 1 to $10 \mathrm{~km}$ from mine spills, the content of water-soluble substances is reduced by 2-3.5 times. The content of water-soluble substances is changed to sulfate-iron-calcium and sulfate-calcium within $\mathrm{pH}$ 5.4-6.7. The content of sulfates decreases by 3-4 times, iron-by $6.5-7$ times and aluminum - by 18-49 times. In these areas, the influence of mine waters is associated with the formation of secondary minerals such as goethite, lepidocrocite, copiapite in river sediments, and with the additional influence of runoff from mine dumps in the sediments are present basaluminite and diaspore.

In the downstream sections of the rivers located several tens of kilometers downstream of the sources of pollution, the composition of the sulfate-calcium extract is comparable to that of the background. However, the content of water-soluble substances in bottom sediments increases by a factor of 1.3-1.9 compared to the previous zone, which is due to an increase in the concentrations of hydrocarbonate and calcium ions. This phenomenon may be due to the fact that the studied rivers in their middle course cut through the carbonate rocks. In addition, the presence of significant amounts of sulfate ions in river water increases the solubility of calcium carbonate. Experimental studies [23] have shown that with $\mathrm{pH}$ increasing the desorption processes of sulfates from sediments increase, 
which naturally increases their content in water. Active transition to aqueous media of $\mathrm{SO}_{4}{ }^{2-}$ for these sites can also be associated with the evolution of crystal mineral phases of ferrous sediments, which is described in the following studies [11,24]. For this area, changes in alluvial sediments are also due to organic matter and finely dispersed coal particles, a significant amount of which is typical for sediments from the Kizel basin rivers. The growth of the total amount of water-soluble substances is rather intensive, but the iron content in the water extraction decreases by 11-16 times and still more exceeds the background in order. The content of moving aluminum forms is reduced to background values. For these river sections, secondary river sediment minerals are represented by goethite, but most iron migrates and accumulates in an amorphous form. Experimental data [6] have confirmed that it is amorphous Fe compounds that can provide deposition of toxic metals from river waters. When physicochemical conditions change, they due to their high reactivity can be a source of toxic metals in river waters. According to the conducted researches $[25,26]$ modern receipts of iron compounds from catchments of the Yaiva and Kosva Rivers in the Kama reservoir exceed volumes of discharge during active mining.

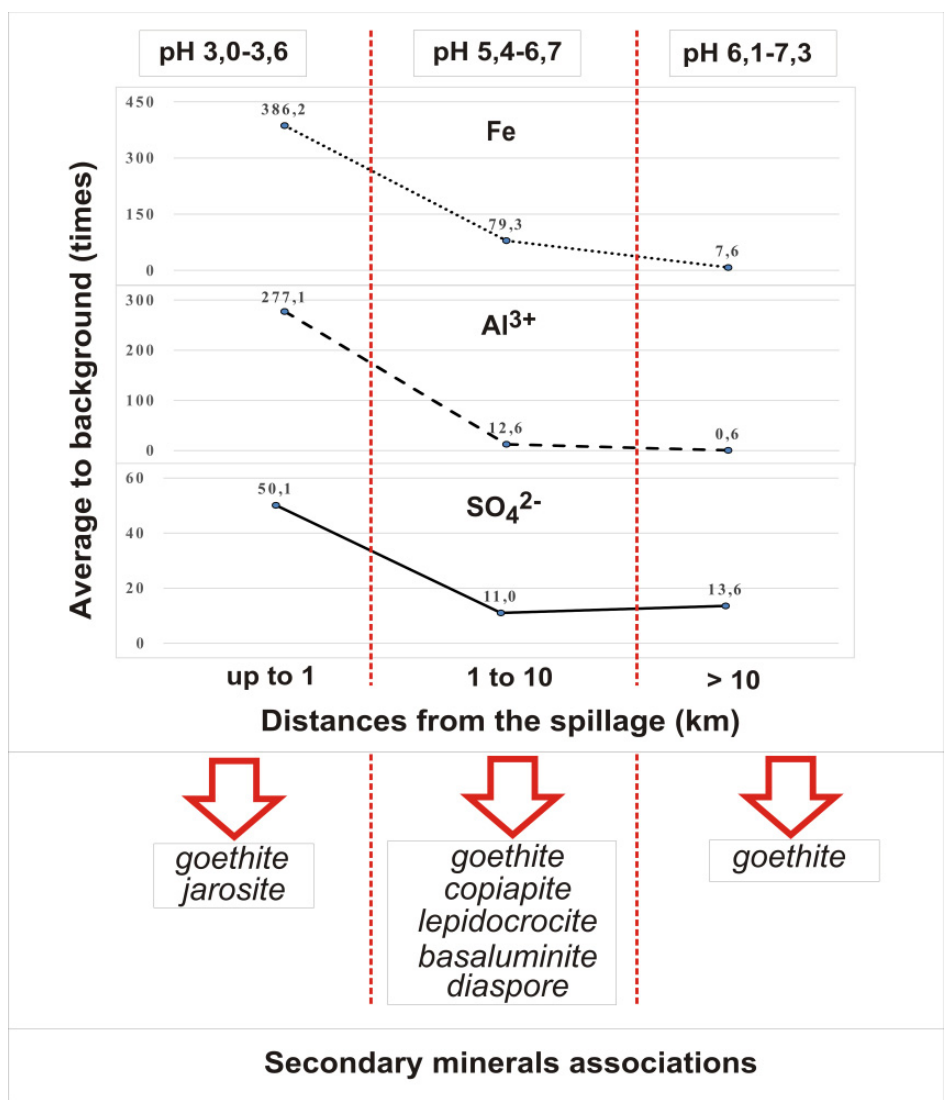

Figure 4. Variation in the content of mobile forms of basic mineral-forming ions in river sediments of the Kizel coal basin.

A study of bottom sediments in the rivers, in which discharging of mine water was stopped after the liquidation of the mines, showed that the $\mathrm{pH}$ values were close to the background (Table 3 ). The content of water-soluble substances is $2.5-4$ times higher than the background values due to increased concentrations in the extraction of sulfate and calcium ions. The content of mobile forms of iron and aluminum slightly exceeds the background values. This demonstrates the deposition role of river sediments in relation to $\mathrm{SO}_{4}{ }^{2-}$, which have good solubility and can easily transfer to river waters. 


\section{Conclusions}

The conducted researches have shown that in zones of intensive technogenic influence modern alluvial deposits are the complexes formed under the influence of both natural and technogenic factors. The study of their composition and occurrence forms of chemical elements allows us to identify the migration flows of matter and areas with different intensity of man-made impact on water bodies.

The river sediments up to $1 \mathrm{~km}$ downstream from mine spills are the most polluted. They are characterized by an acidic reaction of the environment and the highest contents of mobile forms of sulfate, iron and aluminum. However, even in the upper parts of the rivers located several tens of kilometers below the self-discharges, the sulfate and iron content is one order of magnitude higher than the background values. The regularity of changes in the chemical composition of water extraction from bottom sediments has been established: from hydrogen carbonate-calcium in the background areas to sulfate-calcium-iron in the areas adjacent to spills, and sulfate-calcium in the near-surface areas.

The anthropogenic sediments generated by the mixing of mine and river water migrate downstream in the form of suspended load. Washing out occurs particularly intensively during the flood period. Bottom sediments are the most polluted in the areas of rivers below the spillway: the Vilva River-below the town of Gremyachinsk to the mouth (further polluted by the Usva and Chusovaya Rivers), the Kosva River-below the town of Gubakha to the mouth, and the Kizel and Vilva Rivers-below the town of Kizel to the mouth (further polluted by the Yayva River). Under current conditions, the impact of development has been observed in longer sections of rivers than in the period of active coal field development. Accumulated in the backwater zone of the Kama reservoir (downstream sections of the studied rivers), technogenic sediments are a long-term source of secondary pollution of river water. The processes observed actually worsen water quality in the Kama reservoir and the Chusovaya River, which is observed at the water intakes of a number of settlements. Contamination of river water and bottom sediments has a negative impact on the existence and development of aquatic plants and animals.

Further study of mineral forms of occurrence for elements, especially toxic ones, can become the basis for predicting their behavior during migration, on geochemical barriers, in the process of diagenetic transformation. Special attention should be paid to the assessment of emerging sediments as a possible source of secondary water pollution.

Author Contributions: Conceptualization, E.M.; methodology, B.O. and S.B.; investigation, E.M., B.O. and S.B.; writing-review and editing, B.O. and P.B.; visualization, P.B.; project administration, E.M.; funding acquisition, E.M. All authors have read and agreed to the published version of the manuscript.

Funding: The reported study was funded by RFBR, project number 19-05-50071.

Acknowledgments: The authors would like to thank the staff of the nano-mineralogy sector of the "Center for Collective Use of Perm State National Research University" for their assistance in conducting research.

Conflicts of Interest: The authors declare no conflicts of interest.

\section{References}

1. Leeder, M.R. Sedimentology and Sedimentary Basins, 2nd ed.; Wiley-Blackwell: Hoboken, NJ, USA, 2011; pp. 245-294.

2. Blinov, S.; Krasilnikova, S. Using the industrial wastes for remediation of sites affected by acid mine water dumping. In Proceedings of the International Mine Water Association Conference, Perm, Russia, 15-19 July 2019; Khayrulina, E., Wolkersdorfer, C., Polyakova, S., Bogus, A., Eds.; Perm State University, Perm Federal Research Center of the Ural Branch of RAS: Perm, Russia, 2019; pp. 731-735.

3. Fetisova, N.; Fetisov, V.; Bachurin, B.; Imaikin, A. Natural Neutralization of Acid Mine Water in Carbonate Deposits of Kizel Coal Basin. In Proceedings of the International Mine Water Association Conference, Perm, Russia, 15-19 July 2019; Khayrulina, E., Wolkersdorfer, C., Polyakova, S., Bogus, A., Eds.; Perm State University, Perm Federal Research Center of the Ural Branch of RAS: Perm, Russia, 2019; pp. 719-724. 
4. Imaikin, A. Mine waters of Kosva field of Kizel coal basin during and after its operation, forecast of hydrochemical regime of mine waters that are discharged on the surface. In Proceedings of the International Multidisciplinary Scientific GeoConference Surveying Geology and Mining Ecology Management (SGEM2014), Albena, Bulgaria, 17-26 June 2014; pp. 605-612.

5. Berezina, O.A.; Shikhov, A.N.; Abdullin, R.K. Application of multiyear series of space imagery data to assess the environmental situation in coal-mining areas (on the example of the liquidated Kizel coal basin). Curr. Probl. Earth Remote Sens. Space 2018, 15, 144-158. (In Russian) [CrossRef]

6. Consani, S.; Ianni, M.C.; Dinelli, E.; Capello, M.; Cutroneo, L.; Carbone, C. Assessment of metal distribution in different Fe precipitates related to Acid Mine Drainage through two sequential extraction procedures. J. Geochem. Explor. 2019, 196, 247-258. [CrossRef]

7. España, J.S. The Behavior of Iron and Aluminum in Acid Mine Drainage: Speciation, Mineralogy, and Environmental Significance. In Book Thermodynamics, Solubility and Environmental Issues; Letcher, T.M., Ed.; Elsevier: Amsterdam, The Netherlands, 2007; pp. 137-150. [CrossRef]

8. Carbone, C.; Dinelli, E.; Marescotti, P.; Gasparotto, G.; Lucchetti, G. The role of AMD secondary minerals in controlling environmental pollution: Indications from bulk leaching tests. J. Geochem. Explor. 2013, 132, 188-200. [CrossRef]

9. Bigham, J.M.; Nordstrom, D.K. Iron and aluminum hydroxysulfates from acid sulfate waters. Rev. Mineral. Geochem. 2000, 40, 351-403. [CrossRef]

10. Caraballo, M.A.; Rötting, T.S.; Nieto, J.M.; Ayora, C. Sequential extraction and DXRD applicability to poorly crystalline Fe- and Al-phase characterization from an acid mine water passive remediation system. Am. Mineral. 2009, 94, 1029-1038. [CrossRef]

11. Baleeiro, A.; Fiol, S.; Otero-Fariña, A.; Antelo, J. Surface chemistry of iron oxides formed by neutralization of acidic mine waters: Removal of trace metals. App. Geochem. 2018, 89, 129-137. [CrossRef]

12. Maximovich, N.G.; Menshikova, E.A.; Osovetskiy, B.M. Hard technogenic components in alluvium and environment. In Proceedings of the 8th International Congress International Association of Engineering Geology, Vanconver, Canada, 21-25 September 1998; Brookfield: Rotterdam, The Netherlands, 2000; pp. 4579-4582.

13. Menshikova, E.A.; Osovetsky, B.M. Coal particles in the Environment. Probl. Reg. Ecol. 2014, 5, 83-88. (In Russian)

14. Siegel, F.R. Environmental Geochemistry of Potentially Toxic Metals; Springer: Berlin, Germany, 2002; p. 218. [CrossRef]

15. Menshikova, E.A.; Osovetsky, B.M. Technogenic magnetic spherules. In Proceedings of the International Multidisciplinary Scientific GeoConference (SGEM2016), Albena, Bulgaria, 30 June-6 July 2016; Book 3. Water Resources, Forest, Marine and Ocean Ecosystems. Hydrology and Water Resources, Forest Ecosystems;. Curran Associates, Inc.: Makati, Philippines, 2016; Volume 3, pp. 295-302. [CrossRef]

16. Valente, T.M.; Gomes, P.; Sequeira Braga, M.A.; Pamplona, J.; Antunes, I.M.; Ríos Reyes, C.A.; Moreno, F. Mineralogical Attenuation Processes Associated With The Evolution Of Acid Mine Drainage In Sulfide-Rich Mine Wastes. In Proceedings of the International Mine Water Association Conference, Perm, Russia, 15-19 July 2019; Khayrulina, E., Wolkersdorfer, C., Polyakova, S., Bogus, A., Eds.; Perm State University, Perm Federal Research Center of the Ural Branch of RAS: Perm, Russia, 2019; pp. 146-154.

17. Valente, T.M.; Antunes, I.M.; Sequeira Braga, M.A.; Neiva, A.; Santos, A.; Moreno, F. Mobility Control Of Uranium And Other Potentially Toxic Elements In Mine Waters By Ochre-Precipitates. In Proceedings of the International Mine Water Association Conference, Perm, Russia, 15-19 July 2019; Khayrulina, E., Wolkersdorfer, C., Polyakova, S., Bogus, A., Eds.; Perm State University, Perm Federal Research Center of the Ural Branch of RAS: Perm, Russia, 2019; pp. 457-463.

18. Cravotta, C.A. Dissolved metals and associated constituents in abandoned coal-mine discharges, Pennsylvania, USA. Part 1: Constituent quantities and correlations. Appl. Geochem. 2007, 23, 166-202. [CrossRef]

19. Espana, J.S.; Pamo, E.L.; Santofimia, E.; Aduvire, O.; Reyes, J.; Barettino, D. Acid mine drainage in the Iberian Pyrite Belt (Odiel river watershed, Huelva, SW Spain): Geochemistry, mineralogy and environmental implications. Appl. Geochem. 2005, 20, 1320-1356. [CrossRef]

20. Nordstrom, D.K. Hydrogeochemical processes governing the origin, transport and fate of major and trace elements from mine wastes and mineralized rock to surface waters. Appl. Geochem. 2011, 26, 1777-1791. [CrossRef]

21. Valente, T.; Grande, J.A.; de la Torre, M.L.; Gomes, P.; Santisteban, M.; Borrego, J.; Sequeira Braga, M.A. Mineralogy and geochemistry of a clogged mining reservoir affected by historical acid mine drainage in an abandoned mining area. J. Geochem. Explor. 2015, 157, 66-76. [CrossRef] 
22. Nordstrom, D.K. The effect of sulfate on aluminum concentrations in natural waters: Some stability relations in the system $\mathrm{Al}_{2} \mathrm{O}_{3}-\mathrm{SO}_{3}-\mathrm{H}_{2} \mathrm{O}$ at $298 \mathrm{~K}$. Geochim. Cosmochim. Acta 1982, 46, 681-692. [CrossRef]

23. Rose, S.; Ghazi, A.M. Release of sorbed sulfate from iron oxyhydroxides precipitated from acid mine drainage associated with coal mining. Environ. Sci. Technol. 1997, 31, 2136-2140. [CrossRef]

24. Kumpulainen, S.; Carlson, L.; Räisänen, M.-L. Seasonal variations of ochreous precipitates in mine effluents in Finland. App. Geochem. 2007, 22, 760-777. [CrossRef]

25. Dvinskikh, S.A.; Vostroknutova, Y.O.; Kitaev, A.B. The role of technogenic iron in the formation of its content in the water of the Kamskoye and Votkinskoye reservoirs. Geogr. Bull. 2015, 4, 18-25. (In Russian)

26. Lyubimova, T.; Parshakova, Y.; Lepikhin, A.; Tiunov, A. The risk of river pollution due to washout from contaminated floodplain water bodies during periods of high magnitude floods. J. Hydrol. 2016, 534, 579-589. [CrossRef]

(C) 2020 by the authors. Licensee MDPI, Basel, Switzerland. This article is an open access article distributed under the terms and conditions of the Creative Commons Attribution (CC BY) license (http://creativecommons.org/licenses/by/4.0/). 